als architect geïnspireerd was door zijn katholieke geloof werd zijn theoretische visie verrijkt door de praktijk van het ontwerpen en bouwen zelf. In deze hoofdstukken wordt ook de samenwerking onderzocht met Alberdingk Thijm en de zoektocht naar de ware beginselen in de kerkbouw. Het werd voor Cuypers steeds duidelijker dat de essentie van de kerk als betekenisdrager niet moest worden gezocht in de aankleding ervan maar in het gebouw zelf als rationele constructie (125). In hoofdstuk vijf 'Naar een nieuwe stadskerk' toont Oxenaar dat Cuypers een ontwerpsysteem ontvouwt waarbij het gebouw zijn waarde verkrijgt in een stedelijke context. Het moet begrepen worden als antwoord op een specifiek programma voor een specifieke locatie (197). Het is de ontwikkeling van dit meer genuanceerde architecturaal standpunt dat wordt uitgewerkt in de hoofdstukken zes tot elf. De wisselwerking tussen architectuur en stad is duidelijk afleesbaar in de prijsvraag voor het niet gerealiseerde 'Museum Koning Willem l' (1863/1864) en het ontwerp van het Rijksmuseum (1876/1885), beide te Amsterdam. De strakke ideologische neogotiek maakte plaats voor een doordachte rationele ontwerpsystematiek in een wisselende stedelijke context. Cuypers wilde bovenal grote ontwerpen realiseren met een duidelijke maatschappelijke en stedelijke impact. Oxenaar eindigt het boek met een uitgewerkte analyse van het ontwerp en de architecturale doelstellingen van het Rijksmuseum en het Centraal Station in Amsterdam. Het boek is rijkelijk geillustreerd met schetsen en tekeningen van Cuypers zelf.

Op een interessante manier legt Oxenaar het denken van Cuypers bloot. De auteur toont overtuigend aan dat Cuypers gedreven werd door een wisselwerking tussen zijn ontwikkeling van een eigen theoretische visie en het uiteindelijke ontwerp van een gebouw. De tekst is doorspekt met historische details en anekdotes. De bewaarde briefwisseling en persoonlijke documenten worden hiervoor als bron gebruikt. Zulk materiaal brengt de geschiedenis tot leven maar brengt ook risico's met zich mee. Het gebruik van deze bronnen kan vervallen tot een overdreven gedetailleerde reconstructie waarin de hoofdvragen onbeantwoord blijven. Dat is echter hier niet het geval. Oxenaar houdt een goede balans tussen het grote betoog en het historische detail. De anekdotes worden gebruikt om te illustreren hoe Cuypers te werk ging om bepaalde opdrachten binnen te halen, om een theoretische discussie los te maken of zijn standpunten te verscherpen. Met een scherp oog en coherent betoog beschrijft Oxenaar de ontwerpstrategieën van Cuypers en toont aan hoe vooruitstrevend die waren.

Sommige van Oxenaars internationale verwijzingen en referenties zijn te langdradig. Dat hij Cuypers steeds positioneert in een Europees perspectief is goed. Maar de wijdlopige omschrijvingen van de stellingen van Pugin, Violletle-Duc of de jury voor de museumprijsvraag gaan de lezer vermoeien. Het is ook hier dat het boek zich gaat herhalen en als promotiewerk begint aan te voelen. Meestal wordt dit het moment om het boek even terzijde te schuiven. Dit minpunt kan echter geen reden zijn het boek niet te lezen. Oxenaar heeft een boeiend en vlot geschreven boek gepubliceerd en daarmee een waardevolle bijdrage geleverd aan de studie van het architecturale denken van architect Cuypers.

YVES SCHOONJANS, ST. LUCAS - ARCHITECTUUR, ASSOCIATIE K.U. LEUVEN

\section{Nieuwste geschiedenis}

Haan, Ido de, e.a. (eds.), Het eenzame gelijk. Hervormers tussen droom en daad 1850-1950 (Amsterdam: Boom, 2009, 359 blz., ISBN 97890 8506933 1).

In deze opstellenbundel, die is bezorgd ter gelegenheid van het emeritaat van de Amsterdamse historicus Piet de Rooy, wordt onderlinge samenhang gezocht door de focus te richten op 
de figuur van de individuele hervormer en zijn 'eenzame gelijk'. Duidelijker dan het (ideologische) abstractum van maatschappelijke hervorming of 'modernisering', zo luidt de onuitgesproken suggestie, kan deze figuur als seismograaf fungeren van de inhoudelijke verschuivingen en vormveranderingen in de politieke en culturele geschiedenis. Als voorbeeldmetafoor van het gekozen perspectief gelden de politiek-religieuze 'kleine geloven' van de wereldverbeteraars omstreeks 1900 die Romein in zijn Breukvlak herontdekte en die ook De Rooy hebben geïnspireerd.

De eenzaamheid van de 'kleine geloven' mag De Rooy dan zeer hebben geïnteresseerd, hij kan zelf bepaald niet van Einzelgängerei worden verdacht. Politieke historici en cultuurhistorici van uiteenlopende historiografische gezindten, werkzaam in heel verschillende contexten, maken indirect zichtbaar welke centrale rol De Rooy de afgelopen decennia in het Nederlandse historische bedrijf heeft gespeeld. Wat al die gezindten en generaties bindt, is een mengeling van ironische distantie en betrokkenheid. Hier presenteert zich een historisch gilde dat niet in de grote gebaren, maar in de subtiele observatie zijn toevlucht heeft gezocht. Naast een politieke benadering, dringen ideeënhistorische, 'culturalistische' en biografische perspectieven zich haast natuurlijk op om aan die observaties diepte te verlenen.

De eenheid van perspectief verrast en biedt zicht op de koers die de politieke en culturele geschiedschrijving de laatste decennia heeft gevolgd. Een winstpunt is het anti-finalistische karakter dat deze geschiedbeoefening - althans op het eerste gezicht - kenmerkt. Een mooi voorbeeld levert Henk te Velde in zijn opstel over de blijvende relevantie van de negentiendeeeuwse 'kleine geloven'. Hij suggereert dat deze persoonlijke politiek op heel veel verschillende terreinen aanwezig bleef, terwijl historici steeds opnieuw haar ondergang aankondigden. De grens tussen bedachtzame democratische politiek en de moerassen van de 'politieke religie' bleek, anders dan bijvoorbeeld de historici uit de totalitarismeschool volhouden, niet zo eenvoudig te trekken. De pragmatische politiek en het vuur van de overtuiging lijken elkaar nodig te hebben, ook al zitten ze elkaar voortdurend in de weg. Het is een conflict dat ook in de hedendaagse 'populistische' crisis van de politiek blijft spelen.

Het eenzame gelijk levert niet alleen voorbeelden van anti-finalisme. Typerend is ook het brede zicht op de ontwikkeling van de burgerlijke cultuur. Ook hier is de analyse van een breed gedeeld waardepatroon in de plaats getreden van louter socio-economische processen. Op die manier verschoof de aandacht naar nieuwe groepen. In plaats van een beperkt aantal grootindustriëlen, kwamen de dynamische middenklassen in het centrum van de historische belangstelling te staan. Hun cultuur deed, zoals Jouke Turpijn en Jeroen van Zanten aantonen, zelfs het koningshuis van uitzicht veranderen. Precies op het terrein van de voor de erfopvolging zo belangrijke opvoeding zochten de monarchen vanaf de late negentiende eeuw steeds meer aansluiting bij de burgerlijke cultuur van huiselijke verantwoordelijkheid, individuele karaktertraining en pedagogische discipline. Om haar eigen legitimiteit te redden, diende zij haar uitzonderingspositie met een voor iedereen herkenbaar waardepatroon te bekleden. Zij betaalde voor die conformering, weinig verrassend, ook met de neurotische toestanden die door anderen met de ontwikkelingsgang van de burgerlijke cultuur werden verbonden. Dat laatste probleem wordt op een heel andere manier ook gethematiseerd door Leonie de Goei, die suggereert dat de geschiedenis van de geestelijke gezondheid precies als een voertuig van opvoedkundige opvattingen in de bredere geschiedenis van de - burgerlijke - cultuur kan worden ingepast. Ook de interactie tussen burgerlijke morele waarden en materiële cultuur keert op verschillende plaatsen terug. Raf de Bont en Jo Tollebeek, maar ook Bernard Kruithof, Hugo Röling en Marjan Schwegman laten zien wat vlinderverzamelingen, dagboeken en kandelaars met dat waardepatroon te maken hebben. 
De opmerkelijke flexibiliteit van deze middenklasse-cultuur, net zoals haar capaciteit om steeds weer nieuwe invloeden te integreren, vormt ongetwijfeld een belangrijk element van haar blijvende succes. En de nieuwe waardering die de burgerlijke cultuur als geheel de laatste jaren onder historici geniet, heeft dat succes zeker meer inzichtelijk gemaakt. Maar toch heeft deze ontwikkeling ook nadelen. Soms leidt de nieuwe sympathie tot een volledige identificatie tussen deze burgerlijke cultuur en dé Nederlandse geschiedenis - en zelfs tussen deze cultuur en het zelfbeeld van de hedendaagse historici. Op die manier sluipt langs de achterdeur alsnog een nieuw finalisme binnen, van een in zichzelf opgesloten geschiedschrijving, die er niet altijd in slaagt een verband te leggen met de wereld buiten die burgerlijke cultuur. De vraag kan worden gesteld of er, om die grenzen te beslechten, niet opnieuw behoefte is aan een meer synthetiserend en een geëngageerder perspectief.

Dat brengt ons bij de vroege arbeidersbeweging en het socialisme. De Rooy heeft elders betoogd dat de nieuwe sociaaldemocratie alleen succes kon boeken als zij zich in programma en stijl conformeerde aan het liberale progressisme. Maar in deze bundel wordt, zo lijkt het, nog een stap verder gezet. De lezer wordt naar de onuitgesproken conclusie geleid dat radicalere stijlen en opvattingen wezensvreemd zijn aan een Nederlandse geschiedenis waarvan zij nochtans ontegensprekelijk deel hebben uitgemaakt, ook lang na het fin de siècle. Hier dreigt het eenzame gelijk een strafbank te worden, niet alleen voor welbepaalde delen van de historische werkelijkheid, maar ook voor de onwillige lezer die er mogelijk een andere overtuiging op na houdt.

EVERT PEETERS, K.U. LEUVEN, F.W.O.-VLAANDEREN
Paul, Herman, Velde, Henk te (eds.), Het

vaderlandse verleden. Robert Fruin en de

Nederlandse geschiedenis (Amsterdam: Bert

Bakker, 2010, 294 blz., ISBN 978903513544 4).

De aanleiding tot deze bundel is, naar goed vakhistorisch gebruik, een jaartal. In 2010 was het 150 jaar geleden dat Fruins leerstoel werd ingesteld.

Dat is lang genoeg geleden om afstand te kunnen nemen en om een patroon in de receptie van Fruin te onderkennen. De redacteuren zien daarin drie fasen. Zij stellen als het ware drie Robert Fruins aan ons voor. Fruin de Eerste is de negentiende-eeuwse historicus, die methodisch en politiek de maatstaf in het debat was, de instantie die het 'hoogste vonnis' wees, de belichaming van de epistemic virtues. Fruin de Tweede wordt in de twintigste eeuw gehistoriseerd. Hij wordt van gezaghebbende inspiratiebron tot voorwerp van antropologische verwondering. En nu is er dan ruimte voor een derde lezing van Fruin. $\mathrm{Hij}$ is niet langer een onaantastbare autoriteit, maar wel meer dan een cultuurhistorisch curiosum. Fruin is een 'gesprekspartner'.

Deze drieslag correspondeert met drie bredere methodische en inhoudelijke paradigma's. Het rankeaanse paradigma van nationaal en politiek georiënteerd historisme wordt gevolgd door naoorlogse scepsis over nationalistische geschiedschrijving, culminerend in afstandelijke cultuurhistorische beschouwingen over de natie en de nationale historiografie als achterhaalde verschijnselen. Fruin is in dit historiografische paradigma een lieu de mémoire in de zin van Pierre Nora. $\mathrm{Nu}$, in ons huidige paradigma, vinden we dat wat al te gedistantieerd en hooghartig en begeven we ons liever in een weliswaar gelaagde, maar toch direct relevante conversatie met onze voorgangers.

Dat geëngageerde gesprek met vroegere vertegenwoordigers van nog steeds zinvolle tradities verloopt in dit geval toch wat stroef. Herman Paul en Henk te Velde leggen in hun inleiding meteen al uit dat we het over veel dingen die Fruin na aan het hart lagen niet zo graag meer hebben. Alsjeblieft geen etnocentrisme, monarchisme, vaderlandsliefde 